\title{
EFFECTIVENESS OF A MULTI-STAGE BIOFILTER APPROACH AT PILOT SCALE TO REMOVE ODOR AND VOCs
}

\author{
V. TORRETTA ${ }^{1}$, M. RABONI ${ }^{1}$, S. COPELLI ${ }^{1} \&$ P. CARUSON ${ }^{2}$ \\ ${ }^{1}$ Department of Biotechnologies and Life Sciences, University of Insubria, Varese, Italy. \\ ${ }^{2}$ AirClean Srl, Italy.
}

\begin{abstract}
This paper describes an experience conducted to evaluate the performances of a multi-stage approach using a biofiltration process applied to treat exhaust air. In particular, the experimentation was carried out using a pilot plant for the biofiltration of exhaust air from a solid recovered fuel drying process treating the dry fraction of municipal solid waste. Such exhaust streams are characterized by low concentrations of volatile organic compounds and high presence of odorous compounds, such as $\mathrm{H}_{2} \mathrm{~S}$ and $\mathrm{NH}_{3}$. The adopted layout for the experimentation was a multi-stage plant. Each of the two stages (biotrickling filters) used seashells as packing material. In particular, the choice of seashell was defined after the evaluation of the hydrodynamic behavior of different packing materials at the same running conditions. Moreover, some velocity measurements were conducted with the aim at improving the geometry of the reactors and the fan sizing. The multi-stage biofiltration performances indicate that the solutions are suitable as well as applicable for use in industrial plants.

Keywords: Biofiltration, biotrickling filter, fluid dynamics, odor, packing material, pressure drops SRF, VOC.
\end{abstract}

\section{INTRODUCTION}

The strategies for the removal of pollutants destined in the atmosphere are a topic of great importance and at the base of frequent and bitter technical and social confrontations [1].

Air pollution very often regards the strategy for interventions on diffuse source emissions [2-4], but always more frequently they regard punctual emissions, particularly of industrial origin [5]. Focusing the attention on air emission produced in industrial activities, there are several technologies with different application fields, depending on the pollutant to be removed and their concentrations. Traditional volatile organic compounds (VOCs) removal technologies involve physical or chemical processes, such as adsorption, condensation, thermal incineration or catalytic conversion [6]. Very often dust abatement is reached using scrubber and the odor control can be made using adsorption, absorbent or thermal processes. More recently, a lot of applications have been made using biofiltration processes. In fact, biological systems are emerging and attractive technologies for the removal of VOCs present at low concentrations [7-10]. Compared with the traditional physical-chemical technologies, biofiltration presents good performances both considering the removal efficiencies and under the economical point of view (lower investment and management costs) $[11,12]$.

In a biofilter, as the polluted air is passed through a bed of media, the contaminants and oxygen are first transferred to the biofilm formed on the surface of the particles and, then, metabolized by bacteria attached to the filtering media.

In a biotrickling filter (BTF), an aqueous phase is continuously circulated through a bed of inert material. The pollutants in the waste gas and the oxygen are absorbed by the water phase. Biological transformation takes place not only by the action of bacteria attached to the filtering media (biofilm) but also by the action of bacteria contained into the recirculated washing solution. The trickling 
liquid provides moisture, salts, metabolites and supplemental nutrients to the process culture; moreover, it is a convenient mean to control $\mathrm{pH}$ and temperature.

The attention of the present study, extended version of a previous one [13], was on the presence of VOCs $[14,15]$, dust and odors produced in an industrial plant that treats the dry separated waste originated from municipal solid waste (MSW). The effective energy recovery of the solid recovered fuel (SRF) is achieved by directly co-burning in concordance with the new Italian regulation [16-20]. The final destination of the residuals is the landfill. The SRF production needs several operational steps, such as selection, shredding, drying and mixing of fuel with other components with a high calorific value (i.e. chlorine-free plastics resulting from selective collection, rubber scraps and endof-life tires). The process line is performed entirely in a depressurized facility where exists a specific air treatment system applied to the exhaust air and containing:

- One Venturi scrubber for dust abatement pretreatment [21].

- Three chemical scrubbers for treating VOC emissions [21].

The typical off-gas inlet emissions are composed of VOCs $\left(100 \mathrm{mg} \mathrm{Nm}^{-3}\right), \mathrm{H}_{2} \mathrm{~S}\left(10 \mathrm{mg} \mathrm{Nm}^{-3}\right)$, $\mathrm{NH}_{3}\left(10 \mathrm{mg} \mathrm{Nm}^{-3}\right), \mathrm{CO}\left(10 \mathrm{mg} \mathrm{Nm}^{-3}\right)$, NOx $\left(10 \mathrm{mg} \mathrm{Nm}^{-3}\right)$ and dust $\left(15 \mathrm{mg} \mathrm{Nm}^{-3}\right)$. The abatement efficiencies achieved with the existing technologies are around the 50\% (removal efficiencies respect to the inlet contaminants [22]), but this situation does not respect the standards imposed by the Italian technical limits and the requested presented by the Environmental Agency. With more precision, the current limits are, respectively, $15 \mathrm{mg} \mathrm{Nm}^{-3}$ for VOCs (as TOC) and $300 \mathrm{OU} \mathrm{Nm}^{-3}$ for odor compounds.

This paper presents an approach for improving and solving these issues using multi-stage biofiltration systems composed of BTFs [6] with seashell as packing materials. The choice of the packing material (seashell) has been done considering its physical characteristics (high exchange surface, thus promoting mass transfer) and its organic nature that contribute to keeping an ideal environment for bacteria growth (the media within a BTF are normally inert natural or synthetically manufactured materials).

An important item to improve the performances of a BTF, both in terms of pollutants removal efficiencies and reduction of energy cost, is represented by the control of fluid dynamic aspects, with the aim to optimize the geometry of the system and air fan dimensioning.

In fact, fluid dynamics of BTFs, and reactors in general, is of paramount importance for obtaining good performances: a non-uniform distribution of the pollutant into the bed brings to dead zones or bypass, which reduce the bed working volume and, therefore, cause low removal efficiencies. Some experiences concerning the hydrodynamic characterization of BTFs filled with regular packing materials are present in literature [23, 24].

The paper also presents the preliminary results obtained regarding the aeraulic behavior of the BTF pilot plant with seashells as packing material, in comparison with other potential materials available as porous media. Experimental results of bed void fraction and pressure drop at several flow rates were used to obtain Ergun equation coefficients for dry bed. Such coefficients were employed in a commercial finite volume method code to obtain the solution of Reynolds averaged Navier-Stokes (RANS) equations on a Cartesian grid and to obtain the characteristic quantities of the air flow field with an Eulerian approach [25]. Flowfield numerical results in steady-state conditions (numerical simulation) of the reactor flow field carried out with a commercial computational fluid dynamics (CFD) code, validated by the means of local velocity measurements made with a Hot Wire Anemometer (HWA) completed the analysis of the reactor fluid dynamics. 


\section{MATERIALS AND METHODS}

\subsection{Description of the pilot plant}

The processing unit can treat a flow of $1000 \mathrm{~m}^{3} \mathrm{~h}^{-1}$. The biofiltering system is connected to a temporary ductwork system taking air downstream the Venturi scrubber. The plant is composed of two BTFs filled with Mitilus edulis shells (Monashell ${ }^{\circledR}$ patent), treated with a specific process before installation. For some application, the plant can be used in combination with a biofilter that uses granular peat as support media (Monafil ${ }^{\circledR}$ patent) as a final polishing stage.

Each stage of the pilot plant has the following features (Fig. 1):

- Volume: $3.3 \mathrm{~m}^{3}$.

- Packing material height: $0.9 \mathrm{~m}$.

- Trickling liquid flowrate: $0.010 \mathrm{~m}^{3} \mathrm{~min}^{-1}$.

The overall empty bed residence time (EBRT) is $12 \mathrm{~s}$.

The shells, being rich of calcium carbonate $\left(\mathrm{CaCO}_{3}\right)$, exhibit a high buffering power, very efficient for the $\mathrm{pH}$ control (that is an important parameter in particular during the VOCs and odor removal) [26], and a strong affinity for slightly acidic compounds that, even if not present into the off air to be treated, are unavoidably produced during microbial metabolic activities.

No nutrients and oligoelements have been added to the trickling liquid, but an inoculum was made selecting a group of microbial population, in order to lower start-up times and, meanwhile, improve BTFs efficiency. For the inoculums, a special selected mixture of up to 21 microbial species including Pseudomonas species was used.

The plant also includes:

- Two tanks for recirculating, respectively, BTF1 and BTF2 trickling liquid.

- Thermostat-equipped electric heaters controlling trickling liquid temperature. The temperature, which is an essential parameter for the proper functioning of the plant, was set to an ideal value for mesophilic bacteria growth $\left(25^{\circ} \mathrm{C}\right)$.

- A centrifugal fan placed at the end of the treatment chain (each of the treatment stage works under negative pressure). Fan speed was regulated by the means of an inverter.

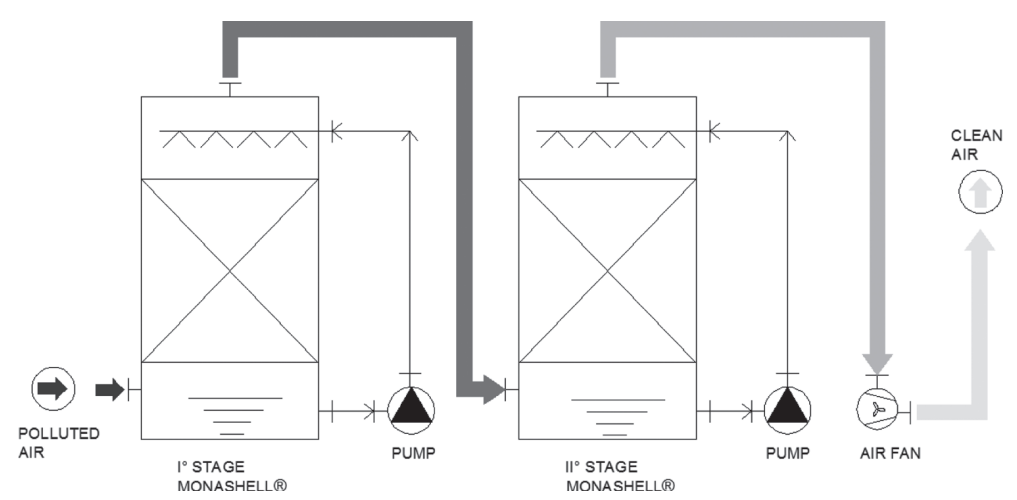

Figure 1: BTFs pilot plant layout. 
The normal operation of the pilot plant produces approximately $0.4 \mathrm{~m}^{3} \mathrm{~d}^{-1}$ of wastewater containing, essentially, salts and other by-products of bacterial oxidation. BTFs wastewaters and biofilter exhaust water were collected into a tank before the treatment in a wastewater treatment plant.

\subsection{Experiments and analysis description}

The pilot plant ran for a period of 8 weeks. At the beginning of the experiment, there was the inoculum and the first 2 weeks were occupied by the acclimatization. During all period of tests, VOCs concentration and odor measurements were monitored, respectively, at the plant inlet and the outlet. VOC's concentrations were measured using FID (UNI EN 121619 method) and GC-MC (UNI EN 131649 method). Olfactometric tests were carried out using forced choice dynamic olfactometry technique (method ISO 13725). Every weekend a microbiological analysis of the exhausted water was carried out.

Air samples were collected onto suitable sorbent tubes using SKC sample pumps. Following desorption, the samples were analyzed by gas chromatography-mass spectrometry (GC-MS). This system consists of a Varian Gas Chromatograph equipped with a high-resolution capillary column interfaced with a Finnigan Matt ITS40 Mass [27].

Pollutant loading $\left(L_{s}\right.$, in $\mathrm{g} \mathrm{h}^{-1} \mathrm{~m}^{-3}$ of packing material) and removal efficiencies $\left(R E_{s}\right.$, as percentage) have been calculated.

\subsection{Fluid dynamic measurements}

Focusing the attention on the first biotrickling filter (BTF1), a series of measures of pressure drops $(\Delta p)$ across the bed were conducted with a Sensirion SDP1000 pressure probe. Sampling and A/D conversion were performed through a Microchip PIC16F87XA connected with a Laptop. A ad hoc $\mathrm{C}++-$ based software managed both acquirement and data storage.

The inlet flow rate $(Q)$ was measured by the means of a Delta Ohm HD 2303.0 Hot Wire Anemometer (HWA; [25]) with a AP471 S1 probe. The HWA was also employed to measure 126 local vertical velocities $\left(|w|, \mathrm{m} \mathrm{s}^{-1}\right)$ in two planes placed, respectively, $0.05 \mathrm{~m}$ below and above the bed $\left(z=0.350\right.$ and $2.450 \mathrm{~m}$ ) during a reactor hydraulic loading rate of $270 \mathrm{~m}^{3} \mathrm{~h}^{-1} \mathrm{~m}^{-3}$ reactor. Because of the HWA characteristics, velocity measurements near the vertical walls were carried out with a Pitot tube [28] connected to the pressure probe. Velocities were sampled for $60 \mathrm{~s}$ : average results were employed for the comparison with the numerical results. Bed porosity, or void fraction ( $\varepsilon$, dimensionless), was determined by measuring bulk volume $\left(V_{\mathrm{ss}}\right)$ and shell mass $\left(m_{\mathrm{ss}}\right)$ :

$$
\varepsilon=\frac{m \rho_{\mathrm{ss}}}{V_{\mathrm{b}}}
$$

where $\rho_{\mathrm{ss}}$ is the seashell density.

The steady-state velocity field simulation was obtained with the CFD code CD-Adapco STARCD 3.26 (Cd-Adapco [29]), which solves the RANS equations using a finite volume scheme with a second-order upwind differentiation for convective terms. Solutions were obtained iteratively by the use of the predictor-corrector SIMPLE (Semi-Implicit Pressure Linked Equations) algorithm [29]. The sensitivity with respect to different turbulence models was tested ( $k-\varepsilon$ standard, $k-\varepsilon \mathrm{RNG})$. The computational mesh consisted in hexahedral cells $0.01 \mathrm{~m} \times 0.01 \mathrm{~m} \times 0.02 \mathrm{~m}$ in the outer region and in a more refined one near the boundaries and into the plenum. The inlet velocity $\left(V_{\text {in }}=5.2 \mathrm{~m} \mathrm{~s}^{-1}\right)$ was assumed to be constant and uniform. Near the solid boundaries, the velocity was assumed to 
follow the standard logarithmic law for a turbulent boundary layer close to a smooth wall; a zero pressure condition was imposed at the outlet.

The seashell bed was modeled as a porous media with an isotropic behavior, which follows the Ergun equation [30]:

$$
\Delta p / h=a U+\beta U^{2}
$$

where, in the Moreno et al. [31] version rewritten for non-spherical particles, $\alpha$ and $\beta$ are:

$$
\begin{aligned}
& \alpha=150 \frac{(1-\varepsilon)^{2}}{\varepsilon^{3}} \frac{\mu_{g}}{36} S_{p}^{2} \\
& \beta=1.75 \frac{1-\varepsilon}{\varepsilon^{3}} \frac{\mu_{g} \rho_{g}}{6} S_{p}
\end{aligned}
$$

where $\mu_{g}$ and $\rho_{g}$ are, respectively, the molecular viscosity and the density of the gas, while $S_{p}$ is the specific surface area of a non-spherical particle [32].

\section{RESULTS AND DISCUSSION}

3.1 VOCs and odor compounds removal

The results for VOCs removal efficiency are shown in Table 1, where input concentrations to the air treatment system $\left(C_{\text {in }}\right)$, and concentrations at the stack $\left(C_{\text {out }}\right)$ were indicated with the overall removal efficiencies of the treatment process.

Table1: VOCs removal efficiency.

\begin{tabular}{lcccc}
\hline Test no. & $\begin{array}{l}\text { Off-gas inlet concentration } \\
\left.(\mathrm{COT}) C_{\text {in }} 9 \mathrm{mg} / \mathrm{Nm}^{3}\right)\end{array}$ & $\begin{array}{l}\text { Off-gas outlet concentration } \\
(\mathrm{COT})\left(C_{\text {out }}\right)\left(\mathrm{mg} / \mathrm{Nm}^{3}\right)\end{array}$ & $\begin{array}{l}\text { Removal efficiency } \\
\left(\mathrm{RE}_{\text {tot }}\right)(\%)\end{array}$ & Method \\
\hline 1 & 54.4 & - & - & Tubes \\
2 & 59.0 & 35.5 & 40 & FID \\
3 & 57.5 & 36.5 & 37 & FID \\
4 & 56.2 & 28.5 & 49 & Tubes \\
5 & 61.6 & 29.3 & 52 & FID \\
6 & - & 26.3 & - & Tubes \\
7 & - & 18.7 & - & Tubes \\
8 & 65.0 & 14.2 & 78 & FID \\
9 & 62.3 & 12.3 & 80 & FID \\
10 & 53.0 & 10.4 & 80 & FID \\
11 & 52.7 & 10.5 & 80 & FID \\
12 & 63.5 & 12.0 & 81 & FID \\
13 & 82.0 & 18.3 & 78 & FID \\
14 & 81.6 & 13.5 & 83 & FID \\
15 & 80.1 & 13.4 & 83 & FID \\
16 & 80.1 & 9.6 & 88 & FID \\
\hline
\end{tabular}


Results demonstrate the importance of a multi-step approach to reach the performances required from the current European environmental regulation. This result was possible because biotrickling technology was used instead of conventional biofiltration. Biofilters can be used only for low concentration airstreams [3], as it was also proven in other study, where a biofilter was adopted as final polishing stage. Moreover, seashells in BTFs offer significant advantage for VOCs removal in terms of $\mathrm{pH}$ control as well as nutrients and micronutrients released by the media. The concentration of VOCs (as TOC) at the final stack is below the limit of $15 \mathrm{mg} \mathrm{Nm}^{-3}$.

Considering the other pollutants, and in particular the odor compounds, the proposed layout permits to reach a considerable reduction of odor concentrations at the outlet stack to less than $300 \mathrm{OU} \mathrm{m}^{-3}$, as shown in Table 2 .

After a period of 2 weeks, which was necessary for bacteria acclimation, the performance of the biofiltration system in terms of average percentage of abatement can be evaluated by the following efficiency parameters:

- Odor removal efficiency:

$95.4 \%$

- VOC removal efficiency: $\quad 81.0 \%$.

The total energy loss is around $60 \mathrm{~mm} \mathrm{H}_{2} \mathrm{O}$ per stage.

To investigate the behavior of the multi stage approach, the same pilot plant was used for testing removal efficiencies in each treatment stage for compounds having different solubility and biodegradability (alcohols and kethons). The adopted layout for this experimentation was a multi-stage plant, where the first two stages were biotrickling filters (BTF1 and BTF2) (seashells as packing material) and the third finishing stage was a biofilter (BF3) (granular peat as packing material).

Results for ethyl acetate are shown in Table 3 where the removal efficiencies after each stage and the overall removal efficiencies of the treatment process were indicated.

The obtained global efficiency is high, also considering a molecule with low biodegradability such as ethyl acetate and thus the worst operating condition. If we consider the results and the removal yields for other compounds (Table 4) at the final working conditions, it is possible to determine the effectiveness of the adopted technical solution. Considering molecules with good

Table 2: Odor concentrations and removal efficiencies.

\begin{tabular}{lccc}
\hline Day & $\begin{array}{c}\text { Odor concentration }- \\
\left.\text { inlet }(\mathrm{OU} \mathrm{Nm})^{-3}\right)\end{array}$ & $\begin{array}{c}\text { Odor concentration - } \\
\left.\text { outlet biofilter }(\mathrm{OU} \mathrm{Nm})^{-3}\right)\end{array}$ & RE $(\%)$ \\
\hline 29 & 4500 & 190 & 95.8 \\
37 & 4880 & 220 & 95.4 \\
51 & 3400 & 180 & 94.7 \\
\hline
\end{tabular}

Table 3: Chemical analysis results on ethyl acetate.

\begin{tabular}{lccccc}
\hline Parameter & m.u. & Test 1 & Test 2 & Test 3 & Test 4 \\
\hline First-stage BTF 1 RE $\left(R E_{1}\right)$ & $\%$ & 40 & 30 & 35 & 47 \\
Second-stage BTF 2 $R E\left(R E_{2}\right)$ & $\%$ & 45 & 40 & 48 & 44 \\
Third-stage BF3 $R E\left(R E_{3}\right)$ & $\%$ & 51 & 73 & 40 & 71 \\
Plant overall $R E\left(R E_{\text {tot }}\right)$ & $\%$ & 84 & 89 & 80 & 91 \\
\hline
\end{tabular}


Table 4: Sampling campaign results with all of the compounds (average data, regarding four tests).

\begin{tabular}{lccc}
\hline Compound & $\mathrm{RE}_{1+2}(\%)$ & $\mathrm{RE}_{3}(\%)$ & $\mathrm{RE}_{\text {tot }}(\%)$ \\
\hline Methoxypropanol & 86.7 & 97.3 & 99.6 \\
MEK & 54.6 & 89.6 & 95.3 \\
Isopropanol & 94.4 & 90.6 & 99.5 \\
Ethyl acetate & 65.3 & 58.8 & 85.7 \\
Ethyl alcohol & 52.5 & 90.6 & 95.5 \\
Other VOCs & -41.5 & 86.3 & -41.7 \\
Total VOCs & 36.2 & 82.6 & 88.9 \\
\hline
\end{tabular}

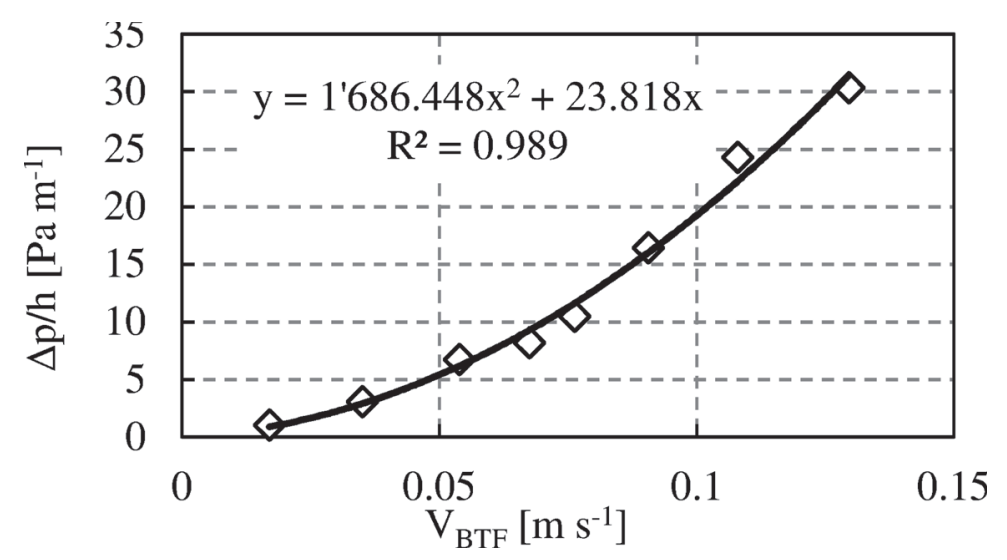

Figure 2: Bed pressure drops at different air velocities.

biodegradability (e.g. methoxypropanol), a removal yield of $99.6 \%$ resulted. Less biodegradable molecules (e.g. MEK and ethyl acetate) also resulted in high removal yields: from $97.8 \%$ for isopropanol to $85.7 \%$ for ethyl acetate. An increase of the other VOCs compounds (with low concentrations) can be due to by-products of biological degradation.

\subsection{Aeraulic behavior of selected packing material}

Considering the fluid dynamic measurements applied to BTF1, results of pressure drop to bed height ratio measurements for dry bed as a function of the mean reactor velocity $\left(V_{\mathrm{BTF}}=Q W^{-1} L^{-1}\right)$ are shown in Fig. 2.

Experimental data were fit very well by a second-order polynomial curve, from which it is possible to obtain $\alpha$ and $\beta$ values for shells. Rewriting eqn (3) or (4), the equivalent specific surface area $\left(S_{p}\right)$ for modified Ergun equation was found. Results are reported in Table 5.

Regarding bed porosity, shells guaranteed a high value (0.90), which indicates both a good biofilm surface to volume ratio and low pressure drops for air.

The HWA measurements confirmed the non-uniform velocity distribution below the bed (at $z=0.35 \mathrm{~m}$ ). Figure 3 shows that vertical velocities $(w)$ before entering in the bed (in plenum at a quote of $z=0.35 \mathrm{~m}$ ) are not uniform: the zone opposite to the inlet has high velocities due to the impinging air jet. Moreover, few zones show even negative velocities caused by recirculation into 
Table 5: Experimental results regarding shells.

\begin{tabular}{lll}
\hline Characteristics & \multicolumn{1}{c}{ Unit } & Value \\
\hline Density, $\rho_{\mathrm{ss}}$ & $\mathrm{kg} \mathrm{m}^{-3}$ & 2688 \\
Bed porosity, $\varepsilon$ & - & 0.90 \\
Ergun equation $\alpha$ & $\mathrm{Pa} \mathrm{s} \mathrm{m}^{-2}$ & 1686 \\
Ergun equation $\beta$ & $\mathrm{Pa} \mathrm{s}^{-3} \mathrm{~m}^{-3}$ & 23.82 \\
Specific surface area, $S_{p}$ & $\mathrm{~m}^{2} \mathrm{~m}^{-3}$ & 9147 \\
\hline
\end{tabular}

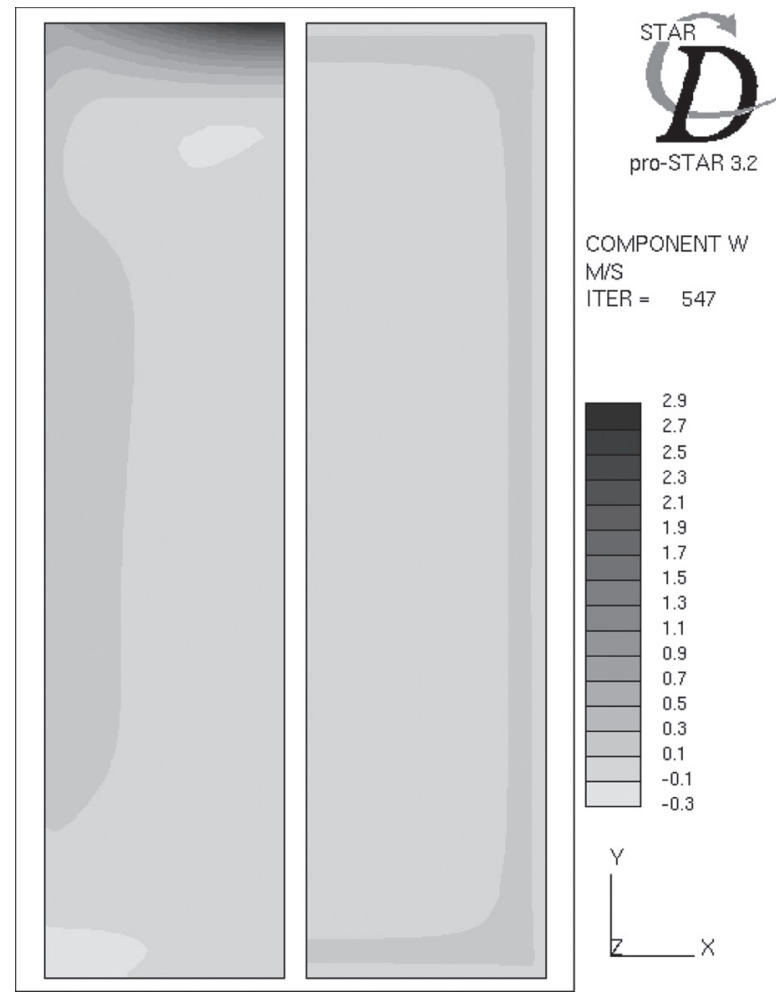

Figure 3: Numerical simulation velocity field at $Z=0.35 \mathrm{~m}$ (plenum - left) and $Z=2.45 \mathrm{~m}$ (BTF1 exit section - right).

the plenum. Such a situation demonstrated that the current inlet configuration did not guarantee a uniform distribution of polluted air into the reactor. Instead, $w$ field outgoing the bed $(z=2.45 \mathrm{~m}$; Fig. 4) is quite uniform thanks to the porous media.

Air velocities above the bed near the wall opposite to the inlet were higher than the average velocity in the section $\left(0.12 \mathrm{~m} \mathrm{~s}^{-1}\right)$; such phenomena demonstrated that an air bypass along the wall existed.

The bypass could defeat the removal efficiencies of the BTF, even if in the remaining part of the field measured air velocities agreed quite well with the numerical results, as demonstrated by the velocity profile (Fig. 4). 


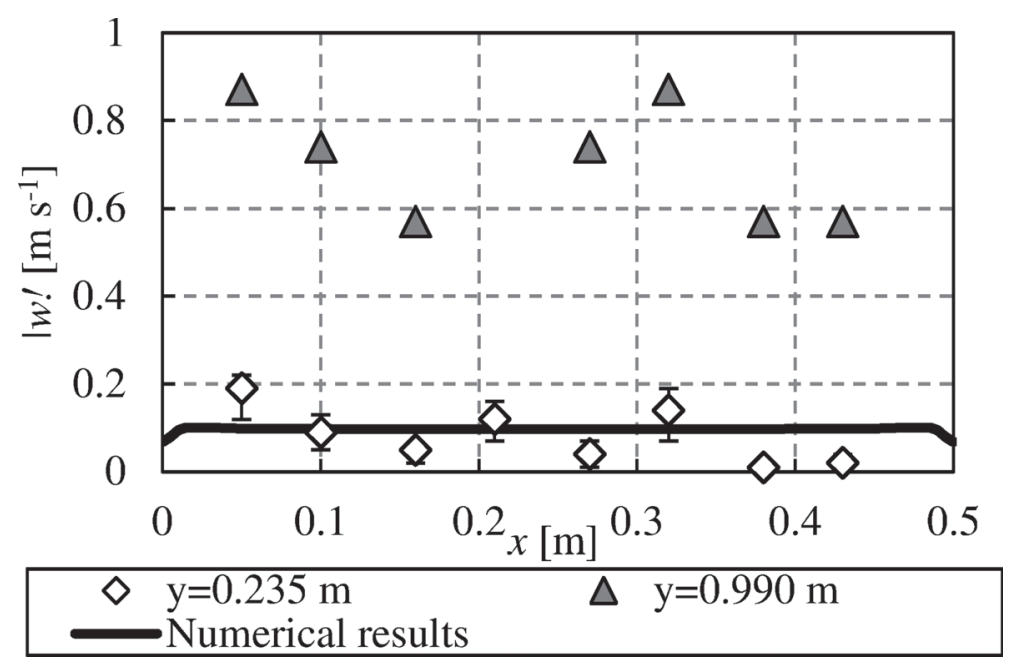

Figure 4: Vertical velocity profiles at $z=1.45 \mathrm{~m}$.

\section{CONCLUSIONS}

In conclusion, it is possible to say that in the considered case study, after the use of BTFs with proper packing materials, the results show very good performances. The odor and VOCs compounds removal yields meet legal standards in the effluent air. This conclusion is in accordance with the technical literature and shows that biofiltration is a natural, energy saving and cost-effective technology, as suggested by European regulations regarding best available technologies and Integrated Pollution, Prevention and Control (IPPC). The results obtained from this study indicate that the pilot plant can be used at full scale for similar applications (low VOCs concentrations with significant presence of odorous compounds). Chemical characteristics of seashells offer significant advantage for VOC removal in terms of $\mathrm{pH}$ control and allow no continuous addition of nutrients rand micro nutrients.

Considering the good results, some specific measurements were conducted on the first stage of BTF1, with the aim to check the fluid dynamic behavior of the reactor. The paper describes the preliminary results obtained with aeraulic measurements (i.e. pressure drop, local velocities) on the first-stage BTF.

Experiments allowed to calculate Ergun equation coefficients and equivalent specific surface area for the packing material used in BTFs (Mytilus edulis shells). Such data can be useful for the correct fan sizing and, as consequence, for reducing construction and management costs.

Numerical simulation of the velocity field into the biofilter plenum demonstrated that a simplified geometrical configuration of the inlet brings to a non-uniform flow distribution, which is also confirmed by velocity measurements. Further developments in the research will be focused on (i) testing new inflow geometries and baffles with experiments and numerical simulations in order to achieve a more uniform air flow distribution and avoid near wall by-pass; (ii) improving numerical simulations, considering also differential packed bed permeability able to simulate the near wall by-pass effects; analyzing pressure drop behavior (iii) of other packing materials (iv) in the presence of varying trickling liquid flow rate.

\section{ACKNOWLEDGEMENTS}

The author acknowledge AirClean S.r.l. (Rho, Milan, Italy) and John Paul Phillips (Bord Na Mòna, Ireland) for their technical support and for making the pilot plants available for this study. 


\section{REFERENCES}

[1] Di Mauro, C., Bouchon, S. \& Torretta, V., Industrial risk in the Lombardy region (Italy): what people perceive and what are the gaps to improve the risk communication and the participatory processes. Chemical Engineering Transactions, 26, pp. 297-302, 2012.

[2] Torretta, V., Rada, E.C., Panaitescu, V. \& Apostol, T., Some considerations on particulate generated by traffic. UPB Scientific Bulletin, Series D: Mechanical Engineering, 74(4), pp. 241-248, 2012.

[3] Ionescu, G., Apostol, T., Rada, E.C., Ragazzi, M. \& Torretta, V., Critical analysis of strategies for PM reduction in urban areas. UPB Scientific Bulletin, Series D: Mechanical Engineering, 75(2), pp. 175-186, 2013.

[4] Torretta, V., Raboni, M., Copelli, S., Rada, E.C., Ragazzi, M., Ionescu, G. \& Apostol, T., Application of strategies for particulate matter reduction in urban areas: an italian case. $U P B$ Scientific Bulletin, Series D: Mechanical Engineering, 75(4), pp. 221-228, 2013.

[5] Opotow, S. \& Weiss, L., Denial and the process of moral exclusion in environmental conflict. Journal of Social Issues, 56(3), pp. 475-490, 2000. doi: http://dx.doi.org/10.1111/00224537.00179

[6] Shareefdeen, Z. \& Singh, A., Biotechnology for Odor and Air Pollution Control, Springer: Heidelberg, Germany, 2004. doi: http://dx.doi.org/10.1007/b138434

[7] Detchanamurthy, S. \& Gostomski, P.A., Biofiltration for treating VOCs: an overview. Reviews in Environmental Science and Biotechnology, 11(3), pp. 231-241, 2012. doi: http://dx.doi. org/10.1007/s11157-012-9288-5

[8] Kennes, C. \& Veiga, M.C., Technologies for the abatement of odours and volatile organic and inorganic compounds. Chemical Engineering Transactions, 23, pp. 1-6, 2010.

[9] Liu, Q., Li, M., Chen, R., Li, Z., Qian, G., An, T., Fu, J. \& Sheng, G., Biofiltration treatment of odors from municipal solid waste treatment plants. Waste Management, 29(7), pp. 2051-2058, 2009. doi: http://dx.doi.org/10.1016/j.wasman.2009.02.002

[10] Mahar, R.B., Yue, D., Liu, J., Zhang, Y. \& Nie, Y., Biological pretreatment of municipal solid waste prior to landfilling. Global Nest Journal, 11(4), pp. 510-517, 2009.

[11] Wang, Z., Govind, R. \& Bitshop, D.F., Review of Biofiltration - Effect of Support Media on Biofilter Performance, NRMRL, U.S. Environmental Protection Agency: Cincinnati, OH, USA, 2006.

[12] Estrada, J.M., Kraakman, N.J.R., Lebrero, R. \& Muñoz, R., A sensitivity analysis of process design parameters, commodity prices and robustness on the economics of odour abatement technologies. Biotechnology Advances, 30(6), pp. 1354-1363, 2012. doi: http://dx.doi. org/10.1016/j.biotechadv.2012.02.010

[13] Torretta, V., Raboni, M., Copelli, S. \& Caruson, P., Application of multi-stage biofilter pilot plants to remove odor and VOCs from industrial activities air emissions. WIT Transactions on Ecology and the Environment, 176, pp. 225-233, 2013. doi: http://dx.doi.org/10.2495/ esus130191

[14] Ragazzi, M., Rada, E.C. \& Antolini, D., Material and energy recovery in integrated waste management systems: an innovative approach for the characterization of the gaseous emissions from residual MSW bio-drying. Waste Management, 31(9-10), pp. 2085-2091, 2011. doi: http://dx.doi.org/10.1016/j.wasman.2011.02.024

[15] Rada, E.C. \& Ragazzi, M., MSW bio-drying: design criteria from a 10 years research. UPB Scientific Bulletin, Series D: Mechanical Engineering, 74(3), pp. 209-216, 2012.

[16] Ragazzi, M. \& Rada, E.C., RDF/SRF evolution and MSW bio-drying. WIT Transactions on Ecology and the Environment, 163, pp. 199-208, 2012. 
[17] Rada, E.C. \& Andreottola, G., RDF/SRF: which perspective for its future in the EU. Waste Management, 32(6), pp. 1059-1060, 2012. doi: http://dx.doi.org/10.1016/j.wasman.2012.02.017

[18] Ragazzi, M., Tirler, W., Angelucci, G., Zardi, D. \& Rada, E.C., Management of atmospheric pollutants from waste incineration processes: the case of Bozen. Waste Management and Research, 31(3), pp. 235-240, 2013. doi: http://dx.doi.org/10.1177/0734242x12472707

[19] Ionescu, G., Zardi, D., Tirler, W., Rada, E.C. \& Ragazzi, M., A critical analysis of emissions and atmospheric dispersion of pollutants from plants for the treatment of residual municipal solid waste. UPB Scientific Bulletin, Series D: Mechanical Engineering, 74(4), pp. 227-240, 2012.

[20] Ragazzi, M. \& Rada, E.C., Multi-step approach for comparing the local air pollution contributions of conventional and innovative MSW thermo-chemical treatments. Chemosphere, 89(6), pp. 694-701, 2012. doi: http://dx.doi.org/10.1016/j.chemosphere.2012.06.024

[21] Perry, R.H. \& Green, D.W., Perry's Chemical Engineers' Handbook, McGraw Hill: New York, NY, 1999.

[22] Rada, E.C., Local environmental impact from MSW aerobic biological treatment. WIT Transactions on Ecology and the Environment, 163, pp. 13-24, 2012.

[23] Trejo-Aguilar, G., Revah, S. \& Lobo-Oehimchen, R., Hydrodynamic characterization of a trickle bed air biofilter. Chemical Engineering Journal, 113, pp. 145-152, 2005. doi: http:// dx.doi.org/10.1016/j.cej.2005.04.001

[24] Sharvelle, S., McLamore, E. \& Banks, M.K., Hydrodynamic characteristics in biotrickling filters as affected by packing material and hydraulic loading rate. Journal of Environmental Engineering, 134, pp. 346-352, 2008. doi: http://dx.doi.org/10.1061/(asce)07339372(2008)134:5(346)

[25] Ferziger, J.H. \& Peric, M., Computational Methods for Fluid Dynamics, 3rd edn., Springer: Berlin, Germany, 2002. doi: http://dx.doi.org/10.1007/978-3-642-56026-2

[26] Cubillas, P., Kohler, S., Prieto, M., Chairat, C. \& Oelkers, E.H., Experimental determination of the dissolution rates of calcite, aragonite, and bivalves. Chemical Geology, 216, pp. 59-77, 2005. doi: http://dx.doi.org/10.1016/j.chemgeo.2004.11.009

[27] Copelli, S., Torretta, V., Raboni, M., Viotti, P., Luciano, A., Mancini, G. \& Nano, G., Improving biotreatment efficiency of hot waste air streams: experimental upgrade of a full plant. Chemical Engineering Transactions, 30, pp. 49-54, 2012.

[28] Arts, T., Boerrigter, H., Carbonaro,M., Charbonnier J-M., Degrez, G., Olivari, D., Riethmuller, M.L. \& Van den Braembusshe, R.A., Measurement Techniques in Fluid Dynamics - An Introduction, von Karman Institute: Rhode-Saint-Genèse, Belgium, 1994.

[29] CDadapco, StarCD 3.26 Manual, 2005.

[30] Ergun, S., Fluid flow through packed columns. Chemical Engineering Process, 48(2), pp. 89-94, 1952.

[31] Moreno, R.M., Antolìn, G. \& Reyes, A., Aerodynamics of a fluidized bed of forestry biomass particles with mechanical agitation. Latin American Applied Research, 39, pp. 11-18, 2009.

[32] Perry R.H. \& Green D.W., Perry's Chemical Engineers' Handbook, McGraw Hill: New York, NY, 1999. 
